\title{
A Case Study on Gob-Side Entry Retaining Technology in the Deep Coal Mine of Xinjulong, China
}

\author{
Ping Wang, ${ }^{1,2,3}$ Li Ding, ${ }^{3}$ Yuan-jun Ma ${ }^{1},{ }^{4}$ Tao Feng, ${ }^{1,2,3}$ Guang-jing Sun, ${ }^{5}$ Yong-jian Zhu, ${ }^{3}$ \\ Heng Ren, ${ }^{3}$ Peng Li, ${ }^{3}$ Yu-qun Zhang, ${ }^{3}$ and Xi-Zhi Wang ${ }^{3}$ \\ ${ }^{1}$ Work Safety Key Lab on Prevention and Control of Gas and Roof Disasters for Southern Goal Mines, Xiangtan 411201, China \\ ${ }^{2}$ Hunan Provincial Key Laboratory of Safe Mining Techniques of Coal Mines, Xiangtan, Hunan 411201, China \\ ${ }^{3}$ School of Resource \& Environment and Safety Engineering, Hunan University of Science and Technology, Xiangtan, \\ Hunan 411201, China \\ ${ }^{4}$ State Key Laboratory of Hydraulics and Mountain River Engineering, College of Water Resource and Hydropower, \\ Sichuan University, Chengdu 610065, China \\ ${ }^{5}$ Shandong Energy Xinwen Mining Group Co., Ltd., Tai'an 271200, China
}

Correspondence should be addressed to Yuan-jun Ma; 460328491@qq.com

Received 9 August 2020; Revised 28 August 2020; Accepted 17 September 2020; Published 29 September 2020

Academic Editor: Jianping Zuo

Copyright (c) 2020 Ping Wang et al. This is an open access article distributed under the Creative Commons Attribution License, which permits unrestricted use, distribution, and reproduction in any medium, provided the original work is properly cited.

Through the analysis of the project of gob-side entry retaining in the deep gangue filling 2305S-2\# working face of the Xinjulong coal mine, the principle and technology of surrounding rock control of gob-side entry retaining along the deep mining face are discussed. It is found that the use of gangue to fill the goaf of the deep mining face can effectively alleviate the occurrence of violent strata pressure, which is the basis for realizing entry retaining along the goaf. In the Xinjulong coal mine, the gangue wall and concrete-filled steel tube columns are used as roadside support structure. Anchor bolt + W steel belt are used as advance support, monomer column + hinged beam are used as temporary support, and long anchor cable + beam are used as permanent support. Gob-side entry retaining of deep mining working face is successfully realized. The actual measurement results show that the bearing capacity of gangue wall increases slowly, and the deformation is large. The concrete-filled steel tube column has a certain drilling bottom, and the roof cable is easily broken on the side of the remaining roadway. It is necessary to strengthen the lateral constraint of the gangue wall, limit the deformation of the gangue wall, and improve the bearing capacity of the gangue wall. The bottom of the concrete-filled steel tube column needs to be installed with a large backing plate to control the bottom drilling amount, and the roof anchor cable of the roadway must have a certain elongation to realize the coordinated deformation of the anchor cable and the roof.

\section{Introduction}

China is rich in coal resources as it is the world's largest coal mining country; however, the loss rate of resources in the process of coal mining is high. The coal lost by coal pillar accounts for $30 \% \sim 40 \%[1,2]$. The coal pillar not only wastes a lot of valuable coal resources but also causes stress concentration affecting the stability of the surrounding rock $[3,4]$. Along the goaf, roadway technology is the key factor to realize coal pillar-free mining in the working face, which improves the recovery of coal mining and relieves the replacement tension of the working face [5-7]. Since the 1970s, China has applied the technology of retaining roadway along the goaf and has made remarkable progress in the form, structure, and material of supporting, which has been successfully popularized and applied in the thin and medium thick coal seam mines with shallow buried depth [8-10]. With the depletion of shallow coal resources, more and more deep coal mining is started. In deep coal mining, there are still some difficulties in the technology of retaining roadway along goaf, such as rockburst, air leakage in goaf, and spontaneous combustion, resulting in frequent mine 
disasters, and thus it seriously restricted the application of the technology in deep coal mining $[11,12]$. In terms of overburden structure, roof fracture position and rotation angle of deep gob-side entry retaining are obviously different from those of shallow gob-side entry retaining [13, 14]. When the mining depth is less than $500 \mathrm{~m}$, the length of the "cantilever beam" and support strength are the main factors affecting the stability of surrounding rock in gob-side entry retaining. When the mining depth exceeds $500 \mathrm{~m}$, the influence of the mining depth gradually increases $[1,15]$. In the aspect of retaining roadway wall materials, there are paste material filling, high water material filling, ordinary concrete material filling, and gangue filling. The paste material is mainly composed of silicate, sand, fly ash, water, and additives. As a roadside support structure, it includes material preparation, transportation, formwork erection, and filling. The determination of relevant parameters of paste material is affected by multiple factors [16]. Because high water material has the advantages of fast maintenance, large postpeak deformation, and high bearing capacity, the roadside support structure is often used for water filling construction [17]. As a filling structure beside the roadway, ordinary concrete has the advantages of high final setting strength, low labor intensity, low cost, and making full use of gangue to reduce the discharge of gangue, but it has the disadvantages of long initial setting time and low initial strength [18]. In terms of surrounding rock deformation, the surrounding rock of gob-side entry retaining in deep mine has the characteristics of rapid deformation, large deformation, and long-term rheological deformation, which is an important reason for the difficulty of retaining roadway along goaf in deep mine $[19,20]$. Therefore, scholars at home and abroad have done a lot of research on surrounding rock control of gob-side entry retaining in deep mine. For example, the ground pressure behavior law of gob-side entry retaining in deep mine, the process of roof rock movement of gob-side entry retaining, the stress distribution characteristics of filling wall, and the control design of support resistance of roadway side filling body are discussed.

Currently, the mining depth of the Xinjulong coal mine of Shandong Xinwen Mining Group has exceeded $900 \mathrm{~m}$, and the coal body and roof belong to weak impact tendency coal rock mass. The research has successfully realized the gob-side entry retaining of 2305S-2\# working face under the condition of weak impact in deep mine, which provides valuable experience for deep coal mining.

\section{The Technology of Gob-Side Entry Retaining in the Deep Gangue Filling Face}

2.1. Geological Conditions. The Xinjulong coal mine is about $12 \mathrm{~km}$ long from north to south, $15 \mathrm{~km}$ wide from east to west, with an area of about $180 \mathrm{~km}^{2}$. The position distribution is shown in Figure 1. The geological reserves are 1.477 billion tons, and the recoverable reserves are 510 million tons. Adopting vertical shaft development method and fully mechanized caving mining method, the design and production capacity is 6 million $\mathrm{t} / \mathrm{a}$, and the service life is 82 years. The main types of coal are fat coal and $1 / 3$ coking coal, which belong to high-quality coking coal with low ash, low sulfur, low phosphorus, and high calorific value.

The 2305 S-2\# gangue filling face of the Xinjulong coal mine is located in the southern wing of -810 level second mining area. The strike length of the working face is $239 \mathrm{~m}$, the inclined length is $120 \mathrm{~m}$, and the buried depth is 920-974 m, which belongs to deep well mining. No. 3 coal is mainly mined in the $2305 \mathrm{~s}^{-2}$ filling face, which is divided into 3 upper coal and 3 lower coal. The thickness of 3 upper coal is $2.3 \sim 3.9 \mathrm{~m}$, with an average of $3.06 \mathrm{~m}$, and the thickness of 3 low coal is $3.0 \sim 6.0 \mathrm{~m}$, containing $3.9-19.3 \mathrm{~m}$ gangue. The 3 upper coal is stable coal seam with a dip angle of $7-10^{\circ}$ and Proctor hardness coefficient $f=1.59$. The working face top and bottom plate situation is shown in Table 1.

Considering the mine is deep with high geostress, the longwall comprehensive mechanized filling mining method is adopted in the 2305s-2\# working face of the Xinjulong coal mine to reduce stress concentration and consume underground gangue. The double drum MG300/730-wd shearer is used to cut and load coal, and the cutting depth is $0.6 \mathrm{~m} .66$ groups of zc9000/20/38 hydraulic filling supports are arranged in the middle of the working face, and one zcg9000/20/38 filling transition support is set at the upper and lower ends, respectively. The underground coal gangue separation system is used to separate the coal and gangue. The gangue is transported to the working face by belt and then transported and filled by the SGZ730/400 scraper conveyor suspended behind the hydraulic support of the working face. The bottom of the scraper conveyor is provided with a gangue unloading hole, and the filling gangue is unloaded to each filling point for repeated unloading and filling. Under the action of the oil cylinder, the gate plate of the gangue discharging hole can be opened and closed along the running direction of the vertical groove, and the gangue filling can be adjusted. At the same time, the gangue is pushed and rammed by tamping rod to make the gangue connected to the top.

Process flow: the coal machine cuts coal to the head or tail of the chute $\longrightarrow$ pulling frame $\longrightarrow$ pushing forward sliding $\longrightarrow$ straightening the multihole bottom unloading conveyor $\longrightarrow$ starting the multihole bottom unloading conveyor $\longrightarrow$ starting the gangue conveying belt of the working face $\longrightarrow$ filling the working face $\longrightarrow$ stopping the gangue conveying belt $\longrightarrow$ stopping the multihole bottom unloading conveyor $\longrightarrow$ cleaning.

\subsection{The Gob-Side Entry Retaining Plan in the Deep Gangue} Filling Face. In the 2305S-2\# waste rock filling working face of the Xinjulong coal mine, the gangue bag barrier and concrete-filled steel tube column were used as side support structure for gob-side entry retaining. The thickness of the gangue wall is $3.0 \mathrm{~m}$, the reinforcement mesh is hung on both sides of the gangue wall, $3.5 \mathrm{~m}$ anchor rod is reserved in the gangue wall, and W steel belt and metal mesh are used to lock the gangue wall. The gangue bags are staggered to ensure the sufficient stubble between the bags and ensure the density of the gangue wall. Concrete-filled steel tubular 


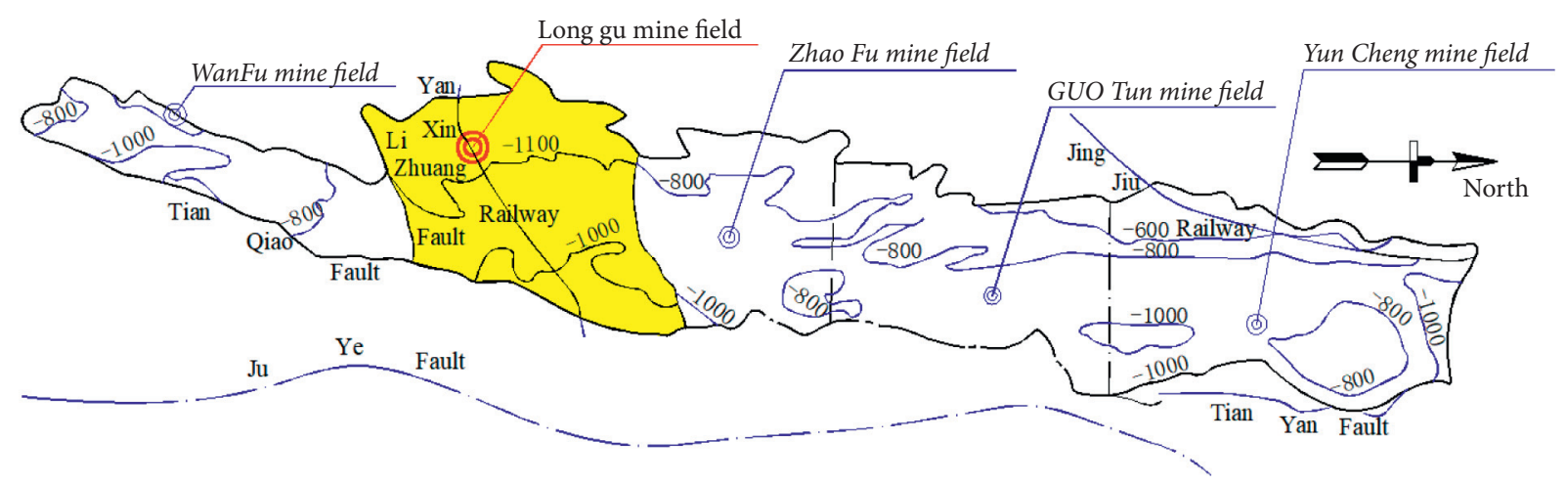

FIgURE 1: Distribution of the coal field in Juye.

TABle 1: Table of coal seam roof and floor.

\begin{tabular}{|c|c|c|c|}
\hline $\begin{array}{l}\text { Name of } \\
\text { strata }\end{array}$ & Name of rock & $\begin{array}{l}\text { Thickness } \\
(\mathrm{m})\end{array}$ & Lithologic description \\
\hline Basic ceiling & Siltstone & 2.30 & $\begin{array}{l}\text { Grayish black, horizontal bedding, upper homogeneous, lower with fine sandstone grain } \\
\text { layer. Pyrrhotite film on lower layer. Vertical fissures developed, filled with pyrite and } \\
\text { calcite, and the upper part contains abundant plant rhizomes and clastic fossils. }\end{array}$ \\
\hline Direct top & $\begin{array}{l}\text { Middle } \\
\text { sandstone }\end{array}$ & 17.80 & $\begin{array}{l}\text { Gray, thin layer, the main components are quartz, feldspar, particle sorting medium, } \\
\text { subcircular, basal type muddy cementation, local development of siderite clams, layered } \\
\text { distribution, forming vein-like bedding, vertical small fissures, filling pyrite film or calcite, } \\
\text { and the core is relatively broken. }\end{array}$ \\
\hline 3 upper coal & - & 2.45 & $\begin{array}{l}\text { Black, brown-black stripe, glass luster, mainly bright coal, secondary dark coal, containing } \\
\text { more mirror coal, occasionally exists silk charcoal, belonging to semibright briquette. } \\
\text { Endogenous fissures are extremely developed. }\end{array}$ \\
\hline \multirow[t]{2}{*}{ Gangue } & Fine sandstone & 1.45 & $\begin{array}{l}\text { Black, blocky, homogeneous, carbonaceous, flat fracture. Fracture development, filling } \\
\text { pyrite and calcite. Rich in plant roots and leaf fossils, local carbonization. } \\
\text { Gray, thin layer, rich in plant stem and leaf fossils and root fossils, common mirror coal } \\
\text { strip and coal line, and oblique small cracks are seen and are filled with pyrite film or } \\
\text { scattered crystal }\end{array}$ \\
\hline & Mudstone & 1.12 & $\begin{array}{c}\text { Black, horizontal bedding, flat fracture surface, uniform, coal clip, rich in plant stem and } \\
\text { leaf fossils }\end{array}$ \\
\hline \multirow{2}{*}{3 lower coal } & \multirow{2}{*}{-} & $\begin{array}{l}2.48 \\
1.80\end{array}$ & \multirow{2}{*}{$\begin{array}{c}\text { Black, brown-black stripe, glass luster, mainly bright coal, secondary dark coal, containing } \\
\text { more mirror coal, occasionally exists silk charcoal, belonging to semibright briquette. } \\
\text { Endogenous fissures are extremely developed and fragile. The bottom coal quality becomes } \\
\text { worse. The gangue is carbonaceous mudstone and lumped. }\end{array}$} \\
\hline & & 0.27 & \\
\hline Counterfeit & $\begin{array}{l}\text { Sandy } \\
\text { mudstone }\end{array}$ & 2.00 & $\begin{array}{l}\text { Dark gray, homogeneous block, flat fracture, containing rhombic nodules, with vertical } \\
\text { fractures, filled calcite, core broken. }\end{array}$ \\
\hline $\begin{array}{l}\text { Direct } \\
\text { bottom }\end{array}$ & Fine sandstone & 4.40 & $\begin{array}{l}\text { Gray, thin layer, even siltstone thin layer, develop slow wave-like bedding, and vein-like } \\
\text { bedding and pyrite thin film are seen and scattered crystal on the bedding surface; the local } \\
\text { particle size is slightly coarse, muddy inclusions or muddy stripes }\end{array}$ \\
\hline Old age & Mudstone & 1.30 & Black, horizontal bedding, flat fracture, homogeneous, rich in plant stem and leaf fossils. \\
\hline
\end{tabular}

columns are set along the roadway direction at $0.5 \mathrm{~m}$ away from the gangue wall, and the column spacing is $2.0 \mathrm{~m}$. The concrete-filled steel tube column is made of $\varphi 159 \mathrm{~mm}$ seamless steel tube, and the two ends are sealed and filled with cement. The wall thickness is $6 \mathrm{~mm}$, and the height is $3.8 \mathrm{~m}$. After the concrete is fully mixed, it is transported to the steel pipe inlet through the wet shotcreting machine and conveying pipe, and the concrete is poured into the steel pipe column from the bottom to top. Sleepers are padded on the top of concrete-filled steel tubular columns for yielding. The height of wooden sleepers is $0.2 \mathrm{~m}$, as shown in Figure 2.

\subsection{Surrounding Rock Control of Gob-Side Entry Retaining}

2.3.1. Support in Front of Roadway along Goaf. The roadway under the $2305 \mathrm{~S}-2$ \# working face is the roadway for gob-side entry retaining, which is used as the return air roadway of the lower section working face. As an auxiliary transport roadway, the roadway is mainly used for coal gangue and air intake and auxiliary material transportation and pedestrians. The net width of roadway is $4.8 \mathrm{~m}$, the net height is $4.0 \mathrm{~m}$, and the net section is $19.2 \mathrm{~m}^{2}$. The roof is supported by the MSGLW-600- $\Phi 22 \times 2500 \mathrm{~mm}$ nonlongitudinal rib-ribbed steel-type resin bolt with a W steel-bar-pressed steel mesh. 


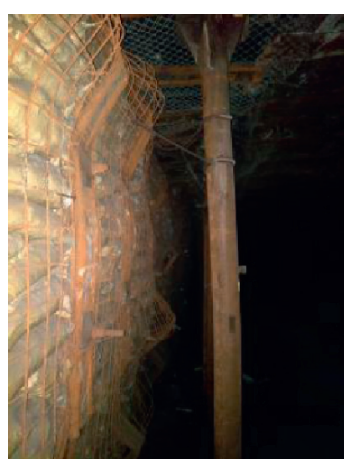

(a)

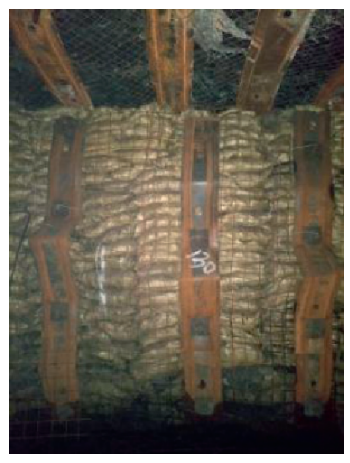

(b)

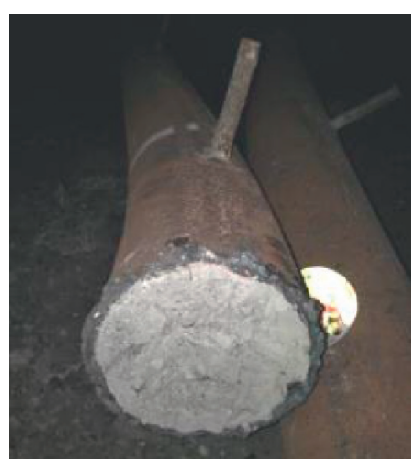

(c)

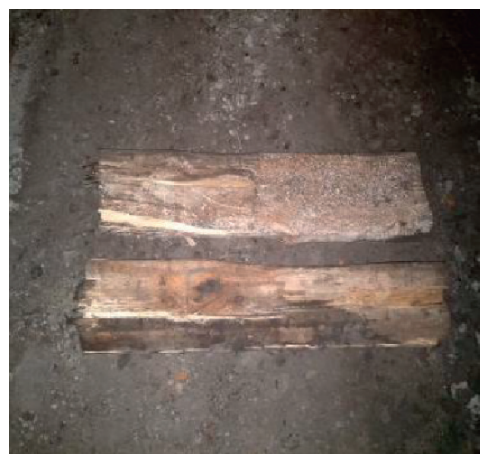

(d)

FIGURE 2: Ribs support structure of gob-side entry. (a) Overall effectiveness. (b) Gangue wall. (c) Concrete-filled steel tube columns. (d) Press square wood.

The two sides use MSGLD-335 of $2500 \mathrm{~mm}$ of strong rebar type resin bolt, the upper side uses the $\mathrm{W}$ steel strip, the lower side uses the belt-type anchor belt and biaxial tensile plastic mesh joint support, and the supporting form before leaving the roadway is shown in Figure 3.

\subsubsection{Temporary Support for Gob-Side Entry Retaining.} With the working face advancing, the roof of the adjacent goaf of the lower roadway is suspended. In order to ensure the space of the roadway along the goaf, the single joint hinged roof beam is used for temporary support at the rear of the tail beam of the working face support with one beam and two columns. The movable column quantity of a single hydraulic prop shall not be less than $0.5 \mathrm{~m}$, and the initial supporting force shall not be less than $90 \mathrm{kN}$. The direction of the hinged top beam is adjusted according to the distance of the empty roof of the tail beam. A row of isolated single pillars, one beam and one column, are set up at $0.5 \mathrm{~m}$ inside the gangue wall, and gangue bags are used to build a retaining wall between the individual buildings to prevent the waste rock from channeling and injuring people in the old goaf. Two rows of monomer, one beam and one column, with a row spacing of $0.8 \mathrm{~m}$ and a filling side of $0.5 \mathrm{~m}$, are supported outside the gangue wall. The maximum distance between the last single supported on both sides of the gangue wall and the tail beam of the support shall not exceed $3 \mathrm{~m}$, as shown in Figure 4.

\subsubsection{Permanent Support for Gob-Side Entry Retaining.} Under the influence of mining, it is necessary to strengthen the anchor cable truss beam between the leading frames of the lower roadway, install the vertical roof of the middle anchor cable, deflect the anchor cable from both sides at a certain angle, and connect with truss along the roadway direction, one with two cables. Using a $\Phi 21.8 \times 6300 \mathrm{~mm}$ high prestressed anchor cable, the anchor cable is arranged between the roof steel belt of roadway, and the distance between anchor cables is $2.0 \times 1.0 \mathrm{~m}$. The anchorage length of the 3 anchorage rolls is less than $1.5 \mathrm{~m}$, and the anchoring tension pretension force should be controlled at $80-100 \mathrm{kN}$. After the construction of anchor cable, the design anchoring force of the single anchor cable should be more than $150 \mathrm{kN}$. Diamond net is laid in front of 1-4 supports at the lower end of the working face, which is laid along with pushing mining. The hanging metal mesh is also used to protect the surface of the solid coal wall, and anchor cable truss beam is used for strengthening support. The anchor cable is installed vertically to coal wall, and one beam and three cables are used to prevent spalling failure of solid coal under high bearing pressure. The permanent support structure is shown in Figure 5.

After the construction of the gangue wall, the reserved anchor rod shall be tensioned at the position of $5 \mathrm{~m}$ behind the tail beam of the support, and the tensile force shall not be less than $20 \mathrm{kN}$. When the tail beam of the support is $20 \mathrm{~m}$ behind, the anchor rod or anchor cable shall be tensioned twice, and the tension shall not be less than $50 \mathrm{kN}$. The lateral restraint of gangue wall is strengthened, the gangue wall bearing is made as soon as possible, and the bearing capacity of gangue wall is improved.

\section{Effect of Gob-Side Entry Retaining in the Deep Mine Gangue Filling Working Face}

3.1. Expansion Deformation and Stress Monitoring of Gangue Walls. An off-layer apparatus is installed horizontally on the gangue wall $50 \mathrm{~m}$ from the cut hole to monitor the expansion and deformation of the gangue wall. Two layers were installed at each station, the ground height being $2 \mathrm{~m}$ and $3 \mathrm{~m}$, respectively. At the same time, the pressure box is installed in the stone wall body to monitor the wall pressure of the retaining gangue in real time. Two pressure boxes (1\# and 2\#) were installed in each group of stations with a spacing of $0.8 \mathrm{~m}, 1.0 \mathrm{~m}$ from the bottom plate, and $1.5 \mathrm{~m}$ installation depth. The installation and monitoring results of the measuring points are shown in Figure 6.

The deformation of the measuring point $2 \mathrm{~m}$ above the ground in the gangue wall changes step by step with the advance of the working face. Within 40 days after the installation of the measuring point, the deformation of the gangue wall gradually increases slowly, and the maximum expansion deformation is only $15 \mathrm{~mm}$. On the 41 st day of monitoring, the deformation of gangue wall suddenly 


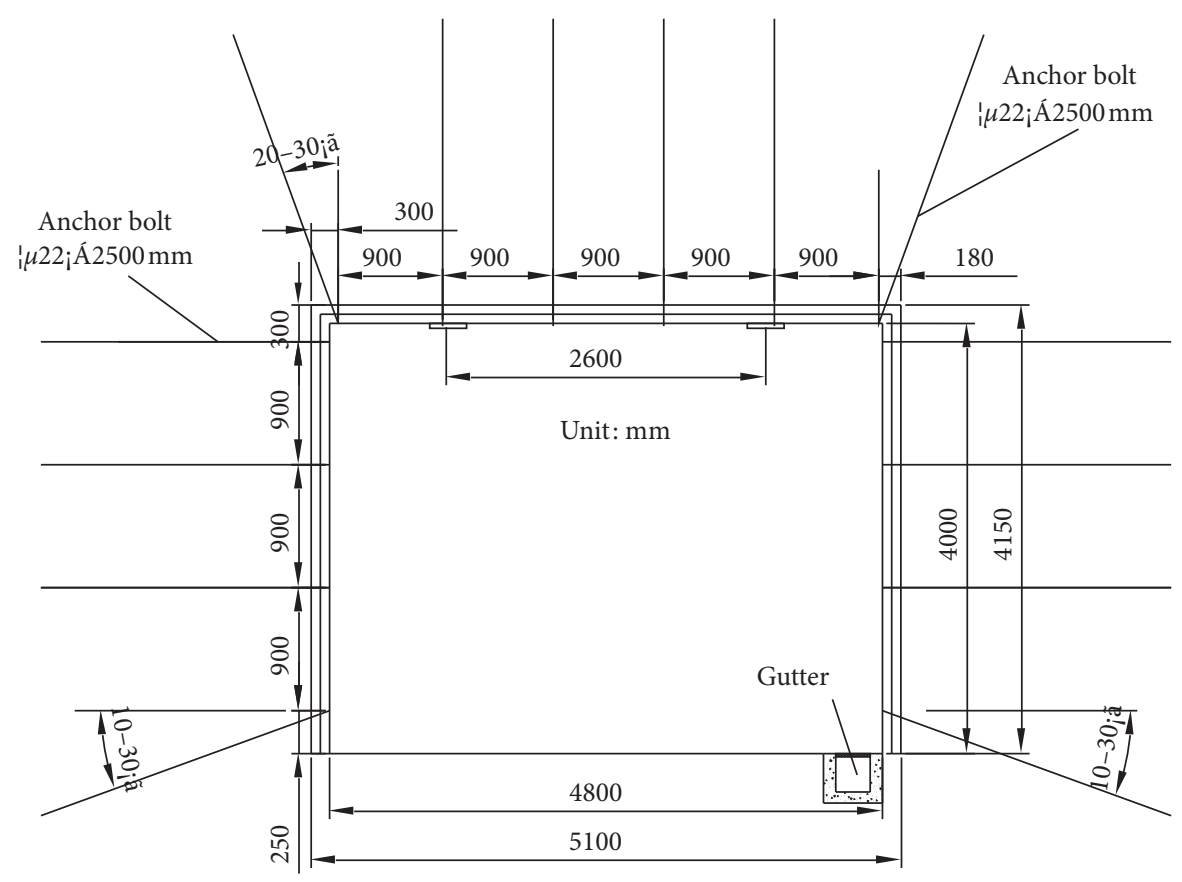

Figure 3: Support structure before gob-side entry retaining.

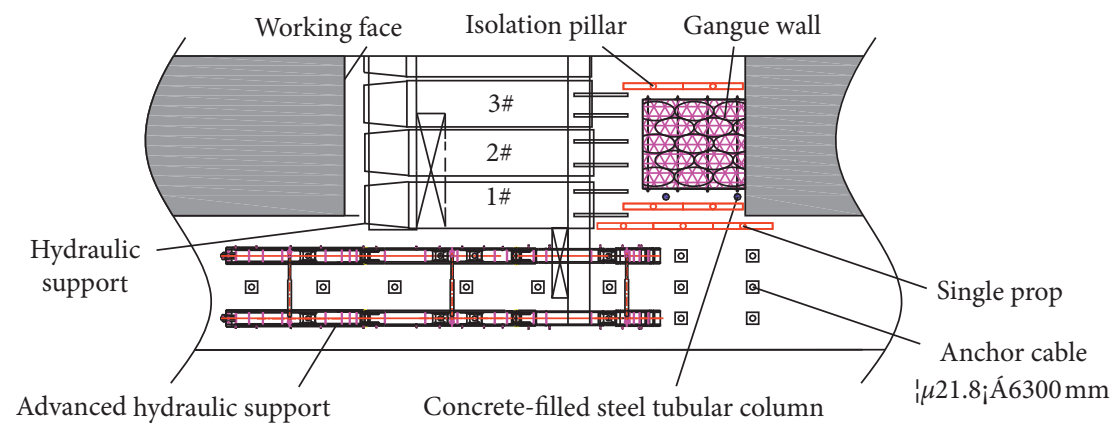

Figure 4: Temporary support of gob-side entry.

increased to $25 \mathrm{~mm}$ and then increased steadily. The final expansion deformation at $2 \mathrm{~m}$ is $35 \mathrm{~mm}$. Along with the first 10 days of working face advancing, the lateral deformation of the gangue wall is very small. It increases approximately linearly from the 11th day, slows down at about 40th day, increases again at the 90th day, and reaches $120 \mathrm{~mm}$ at the 160 th day. Because of the roof subsidence and compression, the upper wall is loaded first and then transferred to the lower part, resulting in the uneven deformation characteristics of the upper part of the gangue wall, which is faster than that of the lower part.

With the increase of time, the stress of the wall increases gradually. About every 10 days, the stress of No. 1 measuring point increases by $0.1 \mathrm{MPa}$. After the stress increases to $0.4 \mathrm{MPa}$, the stress increases to $0.5 \mathrm{MPa}$ after 40 days. The stress change trend of No. 2 measuring point is basically the same. In the process of the gangue wall being compressed, the gangue will be broken again, and the bearing capacity of the gangue wall will increase gradually. The secondary crushing of the gangue leads to the "step-type" change of internal stress in the wall. With the increase of time, the stress of the wall increases gradually. About every 10 days, the stress of No. 1 measuring point increases by $0.1 \mathrm{MPa}$. After the stress increases to $0.4 \mathrm{MPa}$, the stress increases to $0.5 \mathrm{MPa}$ after 40 days. The stress change trend of No. 2 measuring point is basically the same. In the process of the gangue wall being compressed, the gangue will be broken again, and the bearing capacity of the gangue wall will increase gradually. The secondary crushing of gangue leads to the "step-type" change of internal stress in the wall.

3.2. Monitoring of CFST Bottom Drilling. The concrete-filled steel tube (CFST) column, which is one of the supporting structures beside the roadway, has no shrinkage property because of the rigid column itself. Therefore, a yielding sleeper is set at the top of the column for yielding. At the same time, the concrete-filled steel tube column drilling 


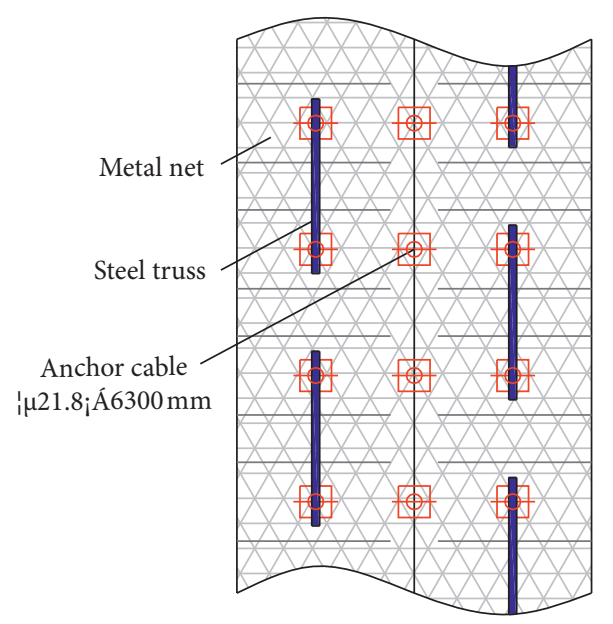

Roof support

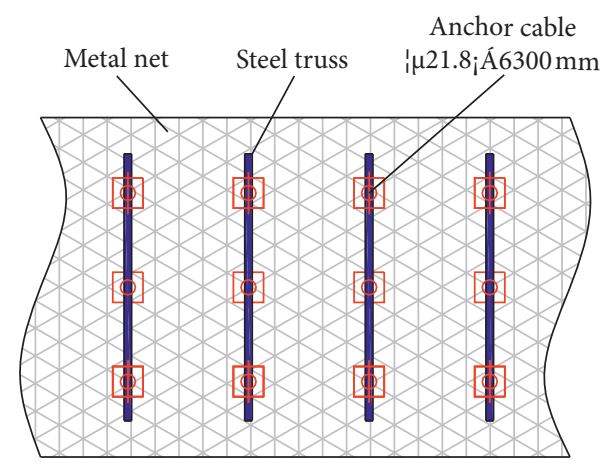

Coal side support

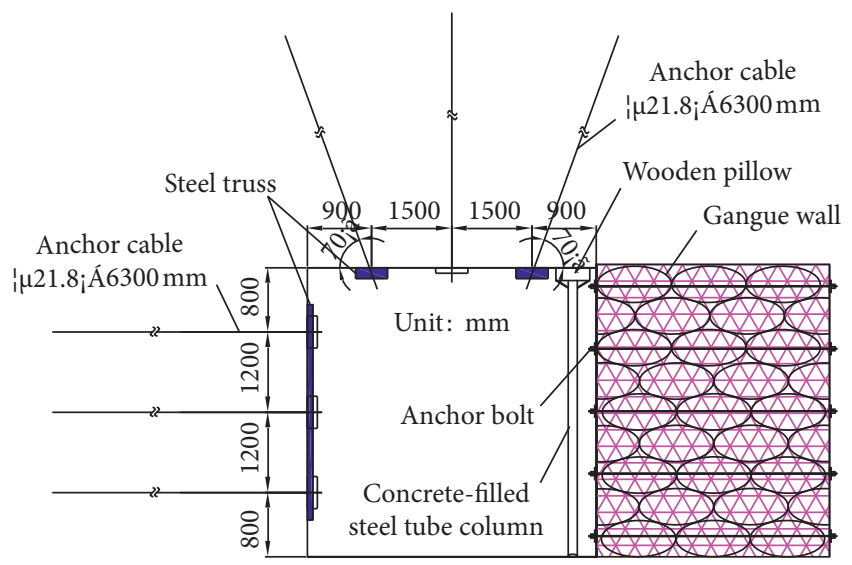

FIgURE 5: Permanent support of the reserved roadway.

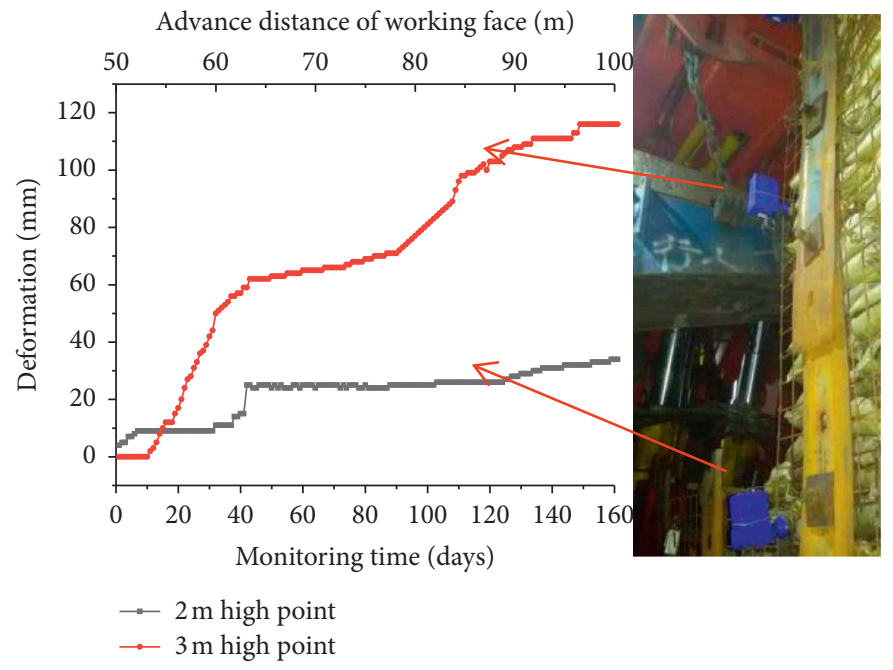

(a)

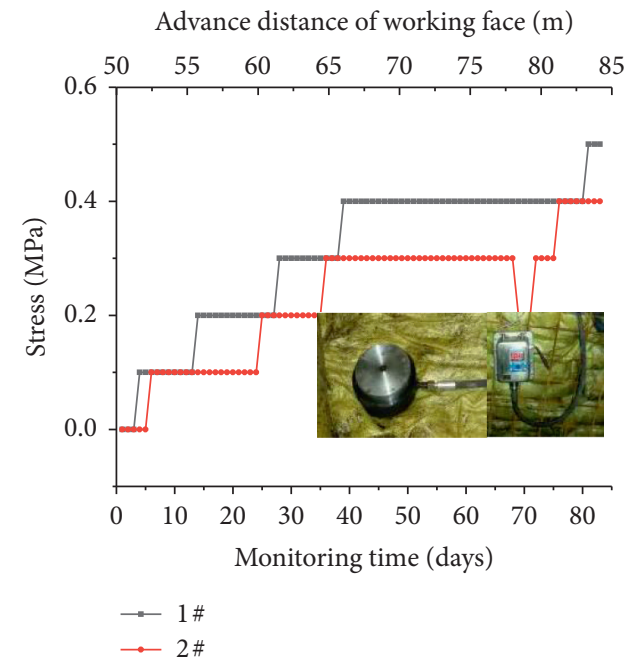

(b)

Figure 6: Stress and deformation characteristics of the gangue wall. (a) Expansion deformation. (b) Stress monitoring.

under pressure also has the pressure yielding effect to a certain extent. However, if the drilling amount of concretefilled steel tubular column is too large, the support resistance of the column is insufficient. Therefore, by drawing a mark line at $1.0 \mathrm{~m}$ above the bottom of the concrete-filled steel tubular column and periodically observing the distance 
between the mark line and the bottom plate of the reserved roadway, the drilling amount of the concrete-filled steel tube pillar is calculated, and its supporting effect is comprehensively evaluated. Starting from the cut hole, the concretefilled steel tube is numbered as No. 1, No. 2, No. 3, ......, in turn. The monitoring results are shown in Figure 7.

The bottom drilling amount of the CFST column increases step by step with the monitoring time, and the overall trend changes in the logarithmic form. It shows that the bottom drilling amount of the concrete-filled steel tube column tends to be stable when the drilling amount increases to a certain extent. It can not only achieve a certain degree of yielding pressure but also provide enough support resistance to achieve better roadway retaining effect.

3.3. Stress Monitoring of Roof Anchor Cables. The anchor cable stress sensor is installed at the roof anchor cable $50 \mathrm{~m}$ away from the cut hole to monitor the stress change of the roof anchor cable. The results are shown in Figure 8.

It can be seen from the figure that the stress of No. 1-3 anchor bolts from the top to the bottom of the gangue wall is relatively small at the initial stage of installation at $50 \mathrm{~m}$ away from the cutoff. The stress of No. 1 and No. 2 anchor bolts is about $8 \mathrm{kN}$ and that of No.3 anchor bolt is about $4 \mathrm{kN}$. With the working face advancing mining, the stress of the gangue wall anchor has an increasing trend, but the increasing range is small. The maximum value of No. 2 bolt installed in the middle of the gangue wall is about $12 \mathrm{kN}$. The roof anchor cable at $50 \mathrm{~m}$ away from the cutoff hole has large stress. The roof anchor cable is numbered 1-3 from the gangue wall side to the solid coal side. The maximum stress of the roof anchor cable is $221.2 \mathrm{kN}, 233 \mathrm{kN}$, and $233 \mathrm{kN}$ respectively When the distance from the working face is $19.8 \mathrm{~m}, 30 \mathrm{~m}$, and $42 \mathrm{~m}$, the maximum value is reached. The stress of No. 1 anchor cable on the side of gangue wall reaches the maximum value and then drops sharply. The force of No. 2 anchor cable in the middle of the roof reaches the maximum value, and then it begins to decline after 12 days. The stress of No. 3 anchor cable on solid coal side reaches the maximum value and keeps stable. After gob-side entry retaining, the subsidence of the roof near the goaf is large, and the elongation of the anchor cable is insufficient, which leads to the failure of the anchor cable. The roof subsidence near the solid coal side is small, and the anchor cable can maintain constant support resistance.

3.4. Overall Effect of Gob-Side Entry Retaining. The Xinjulong 2305S-2\# waste rock filling working face adopts gangue wall and steel tube concrete to retain roadway along goaf. When the working face advances $100 \mathrm{~m}$ from the cut, the deformation of gangue wall, solid coal slope, roof, and floor at $50 \mathrm{~m}$ away from the cut is shown in Figure 9.

After the working face is pushed, the deformation of gangue wall and solid coal side is not large, the roof integrity is good, and the subsidence is small, but the floor heave is large, so it is necessary to strengthen control, but the deformation of surrounding rock of roadway retaining is

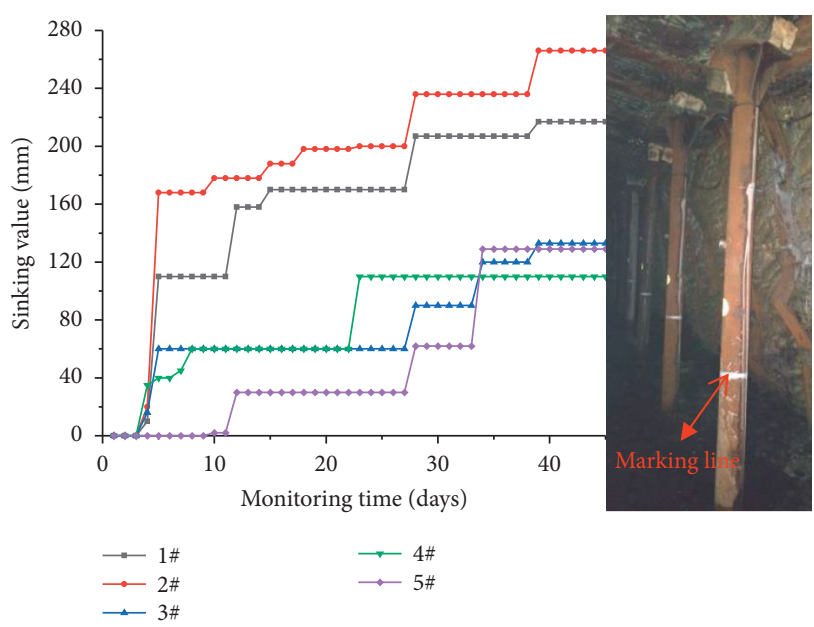

FIGURE 7: Drilling amount monitoring of concrete-filled steel tube columns.

generally within the controllable range, and the roadway retaining along goaf in deep mine is successful.

\section{Discussion}

4.1. Mechanism of Gangue Filling in the Deep Mine Face. Due to the large buried depth, high stress, and severe mining disturbance in the deep mine working face, it shows severe ground pressure behavior. This is the main reason for the difficulty of retaining roadway along goaf in deep mine. Two key problems to realize gob-side entry retaining in deep mine face are to alleviate the severe ground pressure behavior and control the surrounding rock stability of gob-side entry retaining in deep mine face. The reasons for the severe ground pressure behavior in deep mine face are as follows: on the one hand, the high geostress in deep mine; on the other hand, the severe overburden movement caused by strong mining. Filling the goaf with gangue is an effective technical means to effectively alleviate the ground pressure behavior in the deep mine face. After 2305S-2\# gangue filling, the working resistance of hydraulic support is shown in Figure 10. 66 sets of hydraulic supports in the working face are numbered from return air drift to transportation roadway and are divided into three areas. Taking the average value of hydraulic supports in each area, it can be seen that the working resistance of hydraulic supports in the three areas are within the rated working resistance range of supports, and there is no sharp increase in stress. It shows that the severe ground pressure behavior of gangue filling face has been effectively alleviated, which lays a foundation for gob-side entry retaining.

\subsection{Principle of Gob-Side Entry Retaining in the Deep Mine} Face. With the mining of the working face, the surrounding rock of the direct roof experienced stress concentration and mining unloading, resulting in cracks, deformation, and caving. When the ultimate span of the main roof is reached, the main roof will break, rotate, and touch the gangue. After the main roof strata are broken, the large rock masses 


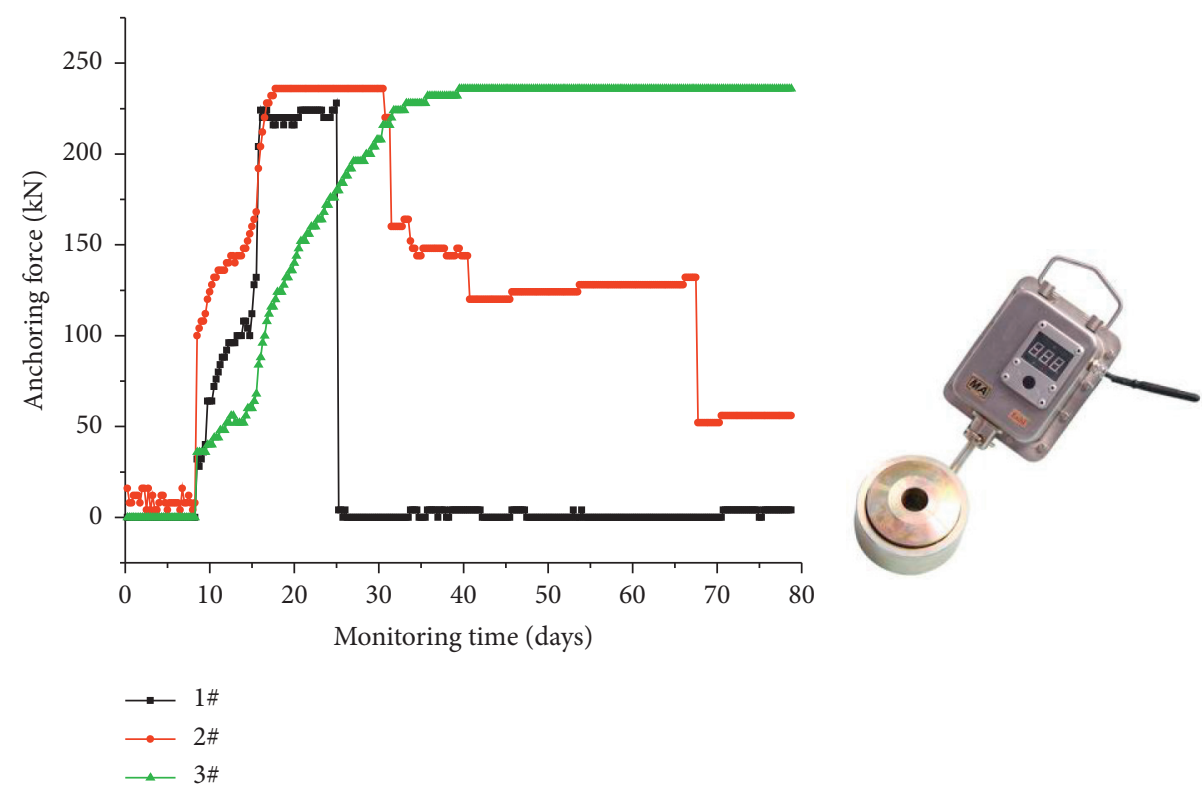

FIGURE 8: Force changes of anchor cable.

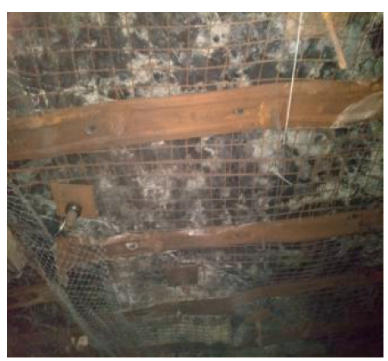

(a)

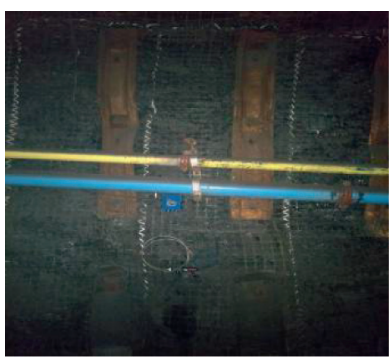

(b)

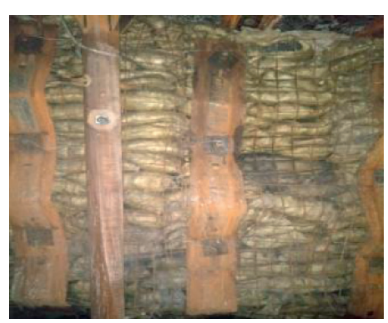

(c)
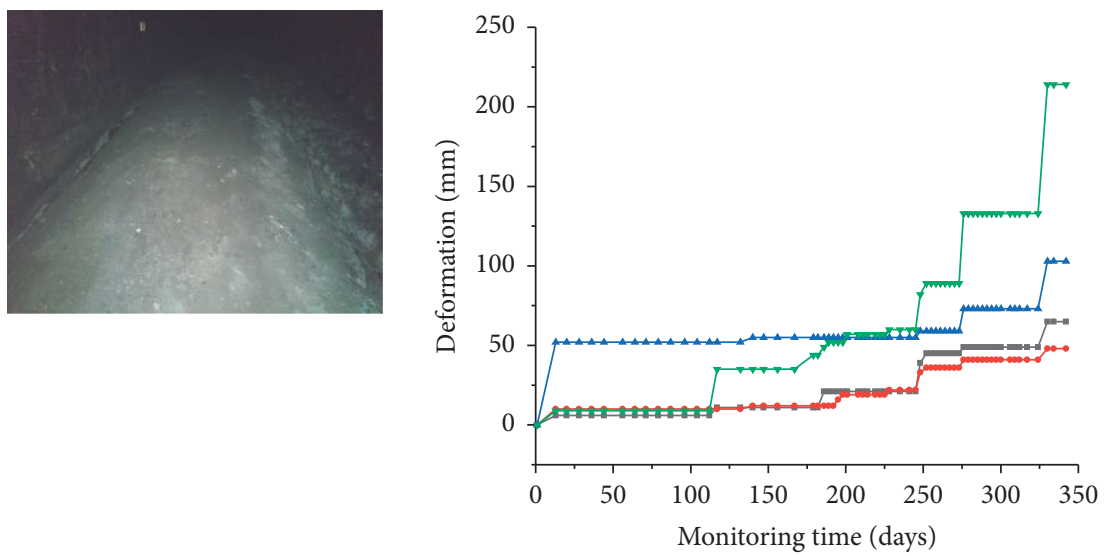

$\rightarrow$ Coal side $\quad \rightarrow$ Roof
$\rightarrow$ Gangue wall $\rightarrow$ Bottom

(e)

Figure 9: Effect of gob-side entry retaining.

squeeze and bite each other in the process of rotation and subsidence, forming a relatively stable "masonry beam" structure under certain conditions [21]. After the overburden of goaf is broken, a cantilever beam structure is formed at the lateral edge of the goaf. Because the "masonry beam" structure is formed in the main roof "cantilever beam" rock block, the surrounding rock under the "cantilever beam" of the main roof is in the state of stress 


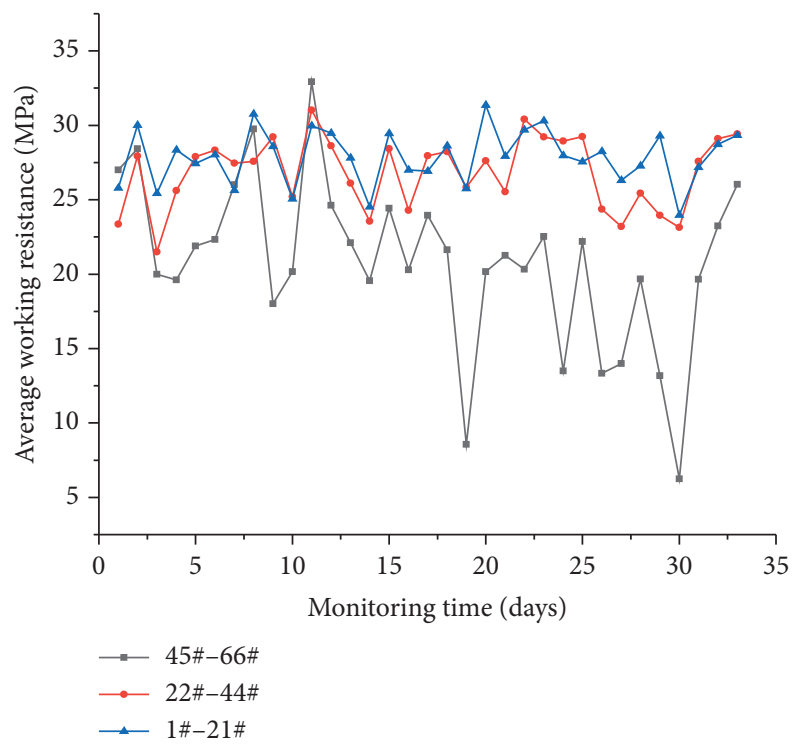

Figure 10: Variation curve of average working resistance of hydraulic support.

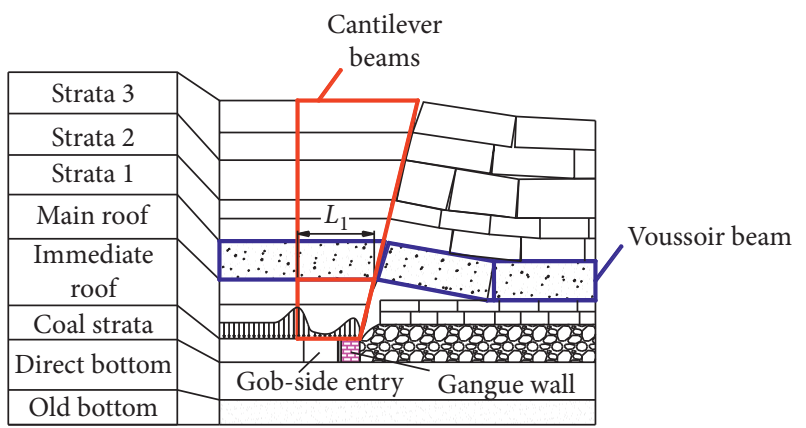

FIGURE 11: Movement rule of gob-side entry.

reduction. The roadway along the goaf is left in the pressurerelief area under the "cantilever beam," so that the surrounding rock of the roadway retaining roadway does not have to bear the high stress caused by deep mining use. However, the stability of surrounding rock of gob-side entry retaining is affected by the main roof "masonry beam." The failure and subsidence of the main roof will cause the coordinated subsidence of several upper strata controlled by the main roof. Every collapse of the overlying rock in the stope will produce certain stress disturbance, which will affect the stability of the surrounding rock of roadway retaining $[22,23]$. However, the length of the cantilever beam formed by the collapse of the overlying strata to the goaf increases with the increase of the height of the collapsed strata. If the overlying strata are farther from the coal seam, the influence of the collapse of the overlying strata on the surrounding rock of the retained roadway will gradually decrease. With the passage of time, the "cantilever beam" of the main roof may break and rotate, and the gangue filling in the goaf will slow down the fracture and rotation of the "cantilever beam" of the main roof. At the same time, the roadway side support body needs to have certain support resistance and collaborative deformation ability, so that the rock block after the "cantilever beam" is broken can rotate slowly and keep stable after a certain rotation angle. The overlying rock structure of gob-side entry retaining is shown in Figure 11.

\section{Conclusions}

Taking the 2305S-2\# deep shaft working face in the Xinjulong coal mine of Shandong Province as an example, the principle and technology of gob-side retaining in deep mine waste filling face are discussed:

(1) Using gangue to fill the goaf of deep mine working face, the working resistance of the hydraulic support of the working face is within the range of rated working resistance, and there is no large stress fluctuation, which can effectively alleviate the severe ground pressure behavior of the deep mine working face, and provide the basis for gob-side entry retaining in the deep mine working face $n$.

(2) Bolt + W steel belt is used for support in front of gobside entry retaining in the deep mine gangue filling working face. Gangue wall and concrete-filled steel tube column are used as roadside support structure. Single body and hinged roof beam are used for temporary support. Long anchor cable and beam are used for permanent support to control solid coal side of roof. Gob-side entry retaining in the deep mine working face is realized successfully.

(3) The monitoring results of gob-side entry retaining in deep mine show that the deformation of gangue wall is uneven after loading, and the internal stress of gangue wall is characterized by increasing "steptype" resistance, and the resistance increase is slow. Therefore, it is necessary to strengthen the lateral restraint after bearing for a certain time to ensure the stability of the gangue wall.

(4) The cantilever beam of gob-side entry retaining in the deep mine face breaks and rotates after retaining roadway. The roof subsidence on one side of the gangue wall is large, and the roof anchor cable should have a certain elongation to realize the coordinated deformation of the anchor cable and roof.

(5) The bottom drilling amount of the concrete-filled steel tube column increases step by step and gradually tends to be stable with the increase of time. However, the deformation of roadway floor along goaf is large, so it is necessary to increase the contact area between concrete column and floor and strengthen floor heave control.

\section{Data Availability}

The data used to support the findings of this study are included in the article, which are based on the geological data of the site. 


\section{Conflicts of Interest}

The authors declare that there are no conflicts of interest regarding the publication of this paper.

\section{Acknowledgments}

This research was funded by the National Natural Science Foundation of China (Grant nos. 51804114, 51774130, and 51974117), the Provincial Natural Science of Hunan (Grant no. 2020JJ5186), the China Postdoctoral Science Foundation (Grant no. 2020M672496), the Postdoctoral Research Foundation of Hunan University of Science and Technology (Grant no. E61803), and Hunan Graduate Education Innovation Project and Professional Ability Improvement Project (Grant no. CX20200985).

\section{References}

[1] N. Zhang, L. Yuan, C. Han, J. Xue, and J. Kan, "Stability and deformation of surrounding rock in pillarless gob-side entry retaining," Safety Science, vol. 50, no. 4, pp. 593-599, 2012.

[2] Z. Q. Song, "Discussion on the development of mining engineering discipline in China and its deep development," Tunnel and Underground Engineering Disaster Prevention, vol. 1, no. 2, pp. 7-12, 2019.

[3] J. X. Xiao, H. Gao, and Y. S. Zhang, "China's coal development in 2017 review and 2018 outlook and recommendations," Energy Situation Analysis Report, vol. 40, no. 1, pp. 5-9, 2018.

[4] M. He, X. Ma, and B. Yu, "Analysis of strata behavior process characteristics of gob-side entry retaining with roof cutting and pressure releasing based on composite roof structure," Shock and Vibration, vol. 2019, Article ID 2380342, 12 pages, 2019.

[5] Y. B. Gao, A Study on the Key Problems of 110 Method of Thick Coal Seam in Caragana Tower Coal Mine Beijing, China University of Mining and Technology, Beijing, China, 2018.

[6] P. Guo, M. He, J. Wang, and H. Zhou, "Test study on multi tray bolt in gob-side entry retaining formed by roof cut and pressure releasing," Geotechnical and Geological Engineering, vol. 35, no. 5, pp. 2497-2506, 2017.

[7] Z. Zhang, X. Yu, and M. Deng, "Damage evolution of sandy mudstone mechanical properties under mining unloading conditions in gob-side entry retaining," Geotechnical and Geological Engineering, vol. 37, no. 4, pp. 1641-1648, 1975.

[8] X. Z. Hua and P. Yang, "A study on the dynamic evolution characteristics of the deformation of the bottom plate of the large section of deep well," Journal of China University of Mining and Technology, vol. 47, no. 3, pp. 494-501, 2018.

[9] C. Yong, J.-B. Bai, X.-Y. Wang et al., "Support technology research and application inside roadway of gob-side entry retaining," Journal of China Coal Society, vol. 37, no. 6, 2012.

[10] C. Han, N. Zhang, J. Xue, and J. Kan, "Multiple and long-term disturbance of gob-side entry retaining by grouped roof collapse and an innovative adaptive technology," Rock Mechanics and Rock Engineering, vol. 52, no. 8, pp. 1-13, 2018.

[11] B. Wu, X. Wang, J. Bai, W. Wu, X. Zhu, and G. Li, "Study on crack evolution mechanism of roadside backfill body in gobside entry retaining based on UDEC trigon model," Rock Mechanics and Rock Engineering, vol. 52, no. 9, pp. 33853399, 2019.

[12] Z. Ma, P. Gong, J. Fan, M. Geng, and G. Zhang, "Coupling mechanism of roof and supporting wall in gob-side entry retaining in fully-mechanized mining with gangue backfilling," Mining Science and Technology (China), vol. 21, no. 6, pp. 829-833, 2011.

[13] J. Yang, M. He, and C. Cao, "Design principles and key technologies of gob side entry retaining by roof pre-fracturing," Tunnelling and Underground Space Technology, vol. 90, pp. 309-318, 2019.

[14] H. P. Kang, D. L. Niu, Z. Zhang, and J. Lin, "Deformation characteristics of surrounding rock and supporting technology of gob-side entry retaining in deep coal mine," Chinese Journal of Rock Mechanics and Engineering, vol. 29, no. 10, pp. 1977-1987, 2010.

[15] G. J. Sun, P. Wang, and T. Feng, "Strata movement characteristics of the deep well gangue filling on the fully mechanized mining face," Journal of Mining \& Safety Engineering, vol. 37, no. 3, pp. 562-570, 2020.

[16] Y. M. Zhao, N. Zhang, and X. G. Zheng, "Structural optimization of overlying strata for gob-side entry retaining in $1000 \mathrm{~m}$ deep mine with direct thick and hard roof," Journal of Mining \& Safety Engineering, vol. 32, no. 5, pp. 714-720, 2015.

[17] Q. Dong, L. B. Liang, and L. Jiang, "Effect of sulfide on the long-term strength of lead-zinc tailings cemented paste backfill," Construction and Building Materials, vol. 200, no. 10, pp. 436-446, 2019.

[18] F. T. Zhang, X. Y. Wang, J. B. Bai, and G. J. Wang, "Post-peak mechanical characteristics of the high-water material for backfilling the gob-side entry retaining: from experiment to field application," Arabian Journal of Geosciences, vol. 13, no. 11 , p. $386,2020$.

[19] S. R. Xie, E. Wang, D. Chen et al., "Failure analysis and control mechanism of gob-side entry retention with a $7.7 \mathrm{~m}$ flexibleformwork concrete wall: a case study," Engineering Failure Analysis, vol. 117, no. 10, pp. 1-16, 2020.

[20] J. Liu, W. Wan, Y. Zhao, and X. Fan, "Stress evolution in punch-through shear tests: a numerical study based on discrete element method," Frontiers in Physics, vol. 8, 2020.

[21] F. X. Jiang, J. C. Wang, and G. J. Sun, "Engineering criteria for impact risk of deep mining along air roadways," Journal of Coal, vol. 40, no. 8, pp. 1729-1736, 2015.

[22] G. J. Sun, S. T. Zhu, F. X. Jiang, and X.-F. Shi, "Safety mining technology of strong dynamic pressure area in deep-well special thick coal seam face," Journal of the China Coal Society, vol. 40, pp. 12-18, 2015.

[23] J. X. Zhang, Q. Zhang, and F. Ju, "Technical system and engineering practice $+\mathrm{X}$ green mining in coal mine," Journal of Coal, vol. 44, no. 1, pp. 64-73, 2019. 